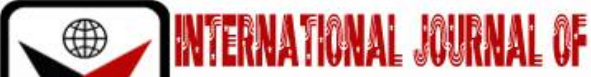

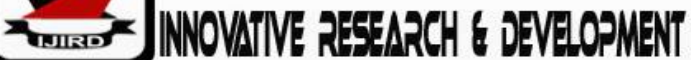

ISSN 2278-0211 (Online)

\section{Gender Differences in Instructional Leadership Style among Primary Head-Teachers: A Case of Kiambu County, Kenya}

\author{
Githaiga Ann Wanjiru \\ Assistant Lecturer, Department of Educational Foundations, \\ Moi University, Kenya \\ Kipsoi Emmy \\ Associate Professor, Department of Educational Foundations, \\ Moi University, Kenya
}

\begin{abstract}
:
Literature has shown that leadership is an important factor influencing school and learner performance. Consequently, leadership exhibited at any institution of learning is widely deemed to be an important aspect. As such, research has repeatedly identified instructional leadership (IL) as one of the characteristics of effective leaders and that demographic characteristics of the head-teacher could have an effect on instructional leadership behaviors. Studies on the gender differences in instructional leadership behavior in Kenya are limited. Therefore this article presents some results of such a study carried out in Kiambu County. The study adopted a quantitative methodology, used a stratified random sampling technique and utilized Instructional Leadership Inventory (ILI) instrument to survey 198 head-teachers of both public and private primary schools in Kiambu County. Descriptive and inferential statistics were used to determine the relationship between IL behavior and gender of the head-teacher. On the overall, the study revealed that there was no significant difference between IL behavior and demographic characteristic of gender as measured in the dimensions of: Managing curriculum, supervising teaching, monitoring student progress, defining mission and promoting instructional development. As such Teacher Service Commission could downplay the gender factor in the appointment of head-teachers of primary schools in Kiambu County as no significant difference exists between male and female head-teachers.
\end{abstract}

Keywords: Leadership, instructional, gender

\section{Introduction}

On the basis of their ability to predict copious workers behaviours, demographic characteristics or personality traits such as gender, age, educational level, experience and ethnicity have been used to establish the traits and behaviors that determine effective leadership (Lojpur, et al., 2014). This has been based on the premise that even in similar situations individual actions may differ (Llewellyn \& Wilson, 2003). Subsequently demographic variables or personality traits described as predictable characteristics of an individual behavior (Llewellyn \& Wilson, 2003) have received extensive research through studying the relationship between demographic characteristics of the leader as a manager of an organization or institution (Krishnan \& Park, 1998; Bella, 2005; Shadare, 2011). Accordingly, studies have investigated the effects of demographic variables as predictors of anxiety levels Ünal-Karagüven, (2015), while Chen et al., (2006), and Ponton et al., 2005 have mentioned that the content of self-directed learning could be explained by demographic variables and more studies have established differences and similarities in the way men and women enact their leadership behaviors (Manning, 2002; Barbuto et al., 2007) among others. The reasoning behind demographic traits or characteristics theory is that age, gender, experience, level of educational and ethnicity of the leader could affect working dynamics of the people which influences organizational goals positively (Kabacoff et al., 2001). Conversely just like leadership and demographic characteristics, Krishnan \& Park (1998) contends that the relationship between demographics and leadership style has also received numerous attentions from researchers. They assert that the leadership style of top managers is heavily influenced by their demographic characteristics with Chen et al. (2005) positing that the aspect of leadership style of both men and women is the most preferred by researchers. However, research regarding leadership style and specifically gender differences in instructional leadership styles' has had little attention in Kenya and therefore this study was conducted to address that need. 


\section{Related Literature}

\subsection{Leadership}

For a number of centuries now, leadership being the most important component of any effective organization is among the most important researched topics and which displays no sign of shrinking (Aldahan, 2020). Having said that, a leader simply put by DuBrin, (2009), and Sheikh (2001), is a person who leads a group of people towards a common goal in order to accomplish the specified objectives. However, Alonderiene \& Majauskaite(2016) opines that providing a universal definition of all the terms that make up leadership is difficult as the concept of leadership has a multidimensional nature. In fact the term leadership means different things to different people (Tabassi \& Bakar, 2010).

There's a real dearth of knowledge in literature about the narrative that assumes that follower performance and satisfaction are positively influenced by leadership (Muchiri, 2011), and that the quality of leadership is linked to institutional effectiveness (Bush, 2020). To emphasis on this point, Leithwood et al., (2006) found that leadership is second only to classroom teaching as an influence on pupil learning while Hallinger, $(2005,2009,2012,2016)$; Robinson et al., 2009,found a powerful link between school leadership and student learning confirming that the principal leadership is paramount. On the same note, Leithwood et al.,2006, conducted a study in the US to investigate the links between school leadership and student learning in 180 schools in 43 districts in North America and confirmed that leadership particularly that of the head-teachers counts.

However without a leadership style, the leader cannot meet the objectives and as such the leadership style the leader adopts matters because employee job satisfaction could be improved by the right leadership style (Alonderiene \& Majauskaite, 2016). Research holds that recognition of effective leadership style is a critical task of all organizations which can only be achieved by flexible leaders because only they can choose the proper style for the appropriate situation (Tabassi \& Bakar, 2010).

Numerous definitions of leadership style exists in literature but which all point to the fact that leadership styles are behavior patterns, which can be grouped according to the specifics of a certain behavior. More precisely, leadership style is the method which the leader chooses to manage his followers or the way in which the leader handles his followers (Sheikh, 2006; Alonderiene \& Majauskaite, 2016.)

\subsection{Instructional Leadership Style}

In the wake of recent findings, the construct of instructional leadership has been found to have a greater and positive impact on student learning. To this end literature has numerous studies in the western countries that have identified instructional leadership as resulting in progressive outcomes in educational leadership (Hallinger, 2005; Robinson et al., 2009; Skaalvik, 2020; Kwan, 2020). That the construct is likely to result in strong effects upon pupil outcomes when the principal focuses on the core business of the school in enhancing effective teaching and learning (Robinson et al, (2009) and Hallinger's (2009).

Bush \& Glover (2014) described instructional leadership style as leadership practices that positively emphasis on supervision of teaching and learning for enhancedlearner outcomes. Consequently, if the leaders are knowledgeable about aspects of instructional behaviors, such as teaching and learning challenges, then as coaches they have a better chance of supporting the learners.

Instructional leadership has been conceptualized through three dimensions that guide the behavior of the leader:

- Firstly, the instructional leader defines the school's mission by determining the central purposesof the school through setting up the school vision and goals and communicating these goals to the entire school community (Hallinger, 2005;Marks \& Printy, 2003;Bellibas, 2017).

- Secondly, develops an effective instructional program focusing on coordinating, controlling, supervising, evaluating of instruction and monitoring student progress (Hallinger, 2005;Marks \& Printy, 2003;Bellibas, 2017).

- Finally, promotes a positive school learning environment which entails protecting instructional time, promoting professional development, maintaining a high visibility, providing incentives for teachers and students and developing high expectations and standards (Hallinger, 2005;Marks \& Printy, 2003;Bellibas, 2017).

The body of research on instructional leadership has yielded further wealth of findings stipulating:

- That instructional leadership has effects on the organization (e.g., school mission and goals, expectations, curriculum, teaching, teacher engagement)

- That instructional leadership has direct and indirect effects on student achievement and a variety of school outcomes (Hallinger, 2005), and

- That instructional leadership has effects on personal characteristics (e.g., gender, training, experience) and the school context (school level, school size, and school social economic status)

In Kenya, the concept of instructional leadership has specifically been examined by various researchers such as Wambui \& Ngaruiya, (2016); Ombonga, (2017); Mutuku, et al., (2017); Mutea, (2015) and accordingly we can conclude that instructional leadership is to some extend practiced by head-teachers of both primary and secondary schools in Kenya.

\subsection{Gender and Leadership Style}

The topic of gender and leadership style has widely been addressed by many management consultants, psychologist, social scientists and other writers (Rahman, \& Lim, 2018; Eagly \& Johnson., 1990). Earlier research on leadership style differences between men and women associated democratic and autocratic style or task-oriented style 
and relationship-oriented style (Due \& Alvesson, 2000; Novel \& Purbasari, 2017). However, research outcomes are contradictory with several findings indicating that women leaders adopt different leadership styles than their male counterparts (Karau\& Eagly, 1999; Kabacoff \& Stoffey 2001; Kim \& Shim, 2003). Conversely, other studies have reported that there is no effect of gender on leadership style (Lojpur et al., 2014), yet another perspective declares that gender does not influence leadership style but rather a product of personality, attributes or characteristics of the individual (Kyriakidou, 2012). Some researchers who posit that differences exits argue that some situations could favour either gender (Rahman \& Lim, 2018).With this in mind, a large 2010 study conducted in Germany collected and analyzed data on demographic, organizational and decision-making characteristics that could be considered important in explaining leadership styles with respect to transformational leadership behavior. The findings demonstrated that men and women leaders were found to be the same Lojpur et al., (2014). Eagly, et al., (1992) meta-analysis of 50 studies on gender and leadership style among principals produced findings where more females than males scored higher on task-oriented style, females mainly adopted a more democratic or participative style than males and on internally oriented leadership style, both females and males scored almost the same. A later meta-analysis study by Eagly\& Carli, (2003), demonstrated that female leaders had stronger ratings on transformational leadership and on transactional leadership on the characteristic of contingent reward behaviors. Furthermore,meta-analysis research conducted between 1987 and 2000 by Kyriakidou et al., (2016) on equality, diversity and inclusion in accounting yielded similar results.

As far as instructional leadership and gender is concerned, research has identified that when compared with their male counterparts, there is a small but statistically significant gender effect, in favor of female principals on the use of instructional leadership style (Hallinger, et al.,2016).

\section{Statement of the Problem}

A great deal of research has been done on demographic factors of gender and leadership but few studies have explored the relationship between gender and leadership style in Kenya and even fewer still on the relationship between gender on the practice of instructional leadership. Therefore this study aims to investigate the gender differences in the use of instructional leadership style among primary school head-teachers in Kiambu County, Kenya.

\subsection{Study Objectives}

This study aims to investigate the differences between the gender trait and the instructional leadership style among primary school head-teachers in Kiambu County, Kenya.

- Hypothesis 1: there is significant difference in instructional leadership styles among male and female headteachers in primary schools.

- Hypothesis 2: there is no significant difference in instructional leadership styles among male and female headteachers in primary schools.

\section{Research Methodology}

This section covers the study population, sampling, measures, results, discussions and conclusions.

\subsection{Study Population}

Kiambu County in Kenya has an estimated 847 primary schools, which formed the total school population for the study. Thus target population of this study comprised of all head-teachers of different gender and age groups of both public and private primary schools in the County. The sample population for the study was done through random stratified sampling method. Elfil \& Negida (2017) attests that in stratified random sampling each unit within a sampling frame has an equal chance of being selected and therefore presenting a high representation of the population under study.

Firstly, the schools were stratified into 12 sub-counties of Kiambu County, then into public and private primary schools. Thus we obtained a total sample of 198 head-teachers. Of these $66 \%$ were males while $34 \%$ were females. The questionnaires were administered personally chiefly through voluntary participation to protect individual confidentiality guarantying promptness and accurate data collection.

\subsection{Measures}

Five subscales of instructional leadership behaviors were measured with the Instructional Leadership Inventory

- Define mission,

- Supervision of teaching,

- Management of curriculum,

- Monitoring of student progress and

- Promoting instructional climate,

The five subscales consisted of 46 behavioral items that were rated on a 5-point Likert-type scale that ranges from 1 (never) to 5 (almost always). These dimensions and items or variables were found to be associated with improvements or gains in student academic achievement (Conoley et al, 1995).

Questionnaire data collected was structured and analysed using the SPSS program. Through statistical treatments, the arithmetic means and standard deviation were calculated; one-way analysis of variance (ANOVA) and t-test were performed and used to draw inferences about differences between the means of two or more groups. For all statistical tests, the level of significance was set at $\mathrm{p}<0.01$ and 0.05 . 


\section{Results}

This section presents the analysed data collected from 198 head-teachers of both public and private primary schools in theKiambu County that responded to the survey. The survey instrument, the instructional leadership inventory, a self-report instrument collected information on the instructional leadership behaviors of:

- Defines Mission,

- Manages Curriculum,

- Supervises Teaching,

- Monitors Student Progress, and

- Promotes Instructional Climate, with demographic characteristics of gender of the respondents. The data collected from the participants were compared to determine the differences of instructional leadership on gender.

\begin{tabular}{|c|c|c|c|}
\hline Defining Mission Scale & $\begin{array}{l}\text { Gender Of Head } \\
\text { Teachers }\end{array}$ & Mean & $\mathrm{T}$ \\
\hline \multirow[t]{2}{*}{ Discuss school goals, purpose, and mission with staff } & Female & 4.1 & \multirow[t]{2}{*}{0.44} \\
\hline & Male & 4.0 & \\
\hline \multirow{2}{*}{$\begin{array}{l}\text { Take advantage of an opportunity to stress and } \\
\text { communicate school goals }\end{array}$} & Female & 3.8 & \multirow[t]{2}{*}{-1.03} \\
\hline & Male & 4.0 & \\
\hline \multirow[t]{2}{*}{ Try to be visible in the school building } & Female & 4.2 & \multirow[t]{2}{*}{-0.73} \\
\hline & Male & 4.3 & \\
\hline \multirow[t]{2}{*}{ Recognize good teaching at formal school ceremonies } & Female & 3.8 & \multirow[t]{2}{*}{-1.66} \\
\hline & Male & 4.0 & \\
\hline \multirow{2}{*}{$\begin{array}{l}\text { Communicate excitement about future possibilities to } \\
\text { staff and students }\end{array}$} & Female & 3.9 & \multirow[t]{2}{*}{-0.68} \\
\hline & Male & 4.0 & \\
\hline \multirow{2}{*}{$\begin{array}{l}\text { Instruct a committee to be creative and innovative in } \\
\text { its work }\end{array}$} & Female & 3.7 & \multirow[t]{2}{*}{-0.50} \\
\hline & Male & 3.8 & \\
\hline \multirow[t]{2}{*}{ Focus on school goals in curriculum development } & Female & 4.3 & \multirow[t]{2}{*}{0.92} \\
\hline & Male & 4.2 & \\
\hline \multirow[t]{2}{*}{ Discuss school goals with students } & Female & 4.0 & \multirow[t]{2}{*}{0.81} \\
\hline & Male & 3.9 & \\
\hline
\end{tabular}

Table 1: Defining Mission Scale for Head-Teachers of Different Gender

\subsection{Defines Mission}

From the results, there was a higher score for female head teachers on discussing school goals, purpose, and mission with staff, focus on school goals in curriculum development and discussing school goals with students.

The schools with male head teachers had a higher score for the rest of the variables on defining mission.

However the difference in score by gender of head-teacher was not significant for all the variables relating to defining school mission as illustrated in Table 1.

\begin{tabular}{|c|c|c|c|}
\hline Manages Curriculum Scale & $\begin{array}{c}\text { Gender Of } \\
\text { School Head }\end{array}$ & Mean & t- \\
\hline \multirow{2}{*}{$\begin{array}{l}\text { Provide information teachers need to plan their work } \\
\text { effectively }\end{array}$} & Female & 4.3 & \multirow[t]{2}{*}{.52} \\
\hline & Male & 4.2 & \\
\hline \multirow[t]{2}{*}{ Insist policies and procedures to be followed } & Female & 4.3 & \multirow[t]{2}{*}{-.64} \\
\hline & Male & 4.7 & \\
\hline \multirow[t]{2}{*}{ Find resources to help staff do a good job } & Female & 4.3 & \multirow[t]{2}{*}{$2.03^{*}$} \\
\hline & Male & 4.0 & \\
\hline \multirow[t]{2}{*}{ Make detailed staff improvement plans } & Female & 4.0 & \multirow[t]{2}{*}{1.69} \\
\hline & Male & 3.8 & \\
\hline \multirow{2}{*}{$\begin{array}{l}\text { Review the fit between curriculum objectives and } \\
\text { achievement }\end{array}$} & Female & 4.0 & \multirow[t]{2}{*}{1.21} \\
\hline & Male & 3.9 & \\
\hline \multirow[t]{2}{*}{ Coordinate curriculum across grade levels } & Female & 4.1 & \multirow[t]{2}{*}{.25} \\
\hline & Male & 4.0 & \\
\hline \multirow[t]{2}{*}{ Provides specific support for curriculum development } & Female & 4.2 & \multirow[t]{2}{*}{.44} \\
\hline & Male & 4.1 & \\
\hline \multirow{2}{*}{$\begin{array}{l}\text { Make sure that lesson plans fit with the stated } \\
\text { instructional objectives }\end{array}$} & Female & 4.3 & \multirow[t]{2}{*}{.73} \\
\hline & Male & 4.2 & \\
\hline
\end{tabular}

Table 2: Managing Curriculum among School Heads of Different Gender

*. Is Significant at 0.05

\subsection{Managing Curriculum by Principals of Different Gender}

Under management of curriculum find resources for staff to do a better job was significantly scored higher for females of primary school head teachers as presented in table 2. 
Even though in most of other variables female heads scored better than their male counterparts, the difference was not significant.

\begin{tabular}{|c|c|c|c|}
\hline Supervises Teaching Scale Criteria & $\begin{array}{c}\text { Gender of } \\
\text { school head }\end{array}$ & Mean & $\mathbf{t}$ \\
\hline \multirow[t]{2}{*}{ Spend time working on teaching skills with a teacher } & Female & 3.9 & \multirow[t]{2}{*}{$2.64^{* *}$} \\
\hline & Male & 3.5 & \\
\hline \multirow[t]{2}{*}{ Observe a class } & Female & 4.1 & \multirow[t]{2}{*}{1.67} \\
\hline & Male & 3.8 & \\
\hline \multirow[t]{2}{*}{ Encourage staff to try their best } & Female & 4.6 & \multirow[t]{2}{*}{1.32} \\
\hline & Male & 4.5 & \\
\hline \multirow[t]{2}{*}{ Communicate high expectation to staff and student } & Female & 4.5 & \multirow[t]{2}{*}{0.59} \\
\hline & Male & 4.4 & \\
\hline \multirow[t]{2}{*}{ Model effective teaching techniques for staff } & Female & 3.9 & \multirow[t]{2}{*}{0.10} \\
\hline & Male & 3.9 & \\
\hline \multirow[t]{2}{*}{ Demonstrate an innovative teaching method for staff } & Female & 3.7 & \multirow[t]{2}{*}{0.47} \\
\hline & Male & 3.6 & \\
\hline \multirow{2}{*}{$\begin{array}{l}\text { Help a teacher develop a specific strategy to increase student } \\
\text { achievement }\end{array}$} & Female & 4.0 & \multirow[t]{2}{*}{1.03} \\
\hline & Male & 3.8 & \\
\hline \multirow[t]{2}{*}{ Try to motivate a staff member } & Female & 4.0 & \multirow[t]{2}{*}{-0.51} \\
\hline & Male & 4.1 & \\
\hline \multirow[t]{2}{*}{ Check to see that staffs are working up to capacity } & Female & 4.2 & \multirow[t]{2}{*}{-0.44} \\
\hline & Male & 4.3 & \\
\hline \multirow[t]{2}{*}{ Demand more effort from a staff member } & Female & 3.9 & \multirow[t]{2}{*}{-0.24} \\
\hline & Male & 4.0 & \\
\hline
\end{tabular}

Table 3: Supervising of Teaching Scale among Head Teachers of Different Gender **.Significant at 0.05

\subsection{Supervising Teaching by Principals of Different Gender}

Female head teachers spent significantly more time working on teaching skills with a teacher than male teachers as demonstrated in Table 3.

In other variables related to supervising teaching, there was no significant difference in performance between male and female head teachers.

\begin{tabular}{|c|c|c|c|}
\hline Monitors Student Progress Scale Criteria & $\begin{array}{c}\text { Gender of Head } \\
\text { Teacher }\end{array}$ & Mean & $t$ \\
\hline \multirow[t]{2}{*}{ Review a student's performance with a teacher } & Female & 4.0 & \multirow[t]{2}{*}{1.20} \\
\hline & Male & 3.8 & \\
\hline \multirow{2}{*}{$\begin{array}{l}\text { Stress the importance of achieving top test scores } \\
\text { to teachers }\end{array}$} & Female & 4.1 & \multirow[t]{2}{*}{-0.26} \\
\hline & Male & 4.2 & \\
\hline \multirow{2}{*}{$\begin{array}{l}\text { Use student assessment information to gauge } \\
\text { progress toward the school's goals }\end{array}$} & Female & 4.3 & \multirow[t]{2}{*}{1.02} \\
\hline & Male & 4.1 & \\
\hline \multirow{2}{*}{$\begin{array}{l}\text { Discuss results with faculty to determine areas of } \\
\text { strength and weaknesses }\end{array}$} & Female & 4.2 & \multirow[t]{2}{*}{0.68} \\
\hline & Male & 4.1 & \\
\hline \multirow{2}{*}{$\begin{array}{l}\text { Inform teachers, pupils and community of } \\
\text { assessments results through newsletters, memo, } \\
\text { assemblies and other media }\end{array}$} & Female & 3.7 & \multirow[t]{2}{*}{-0.53} \\
\hline & Male & 3.8 & \\
\hline \multirow{2}{*}{$\begin{array}{l}\text { Use the work and projects of student as part of the } \\
\text { instructional evaluation }\end{array}$} & Female & 3.6 & \multirow[t]{2}{*}{1.77} \\
\hline & Male & 3.3 & \\
\hline \multirow{2}{*}{$\begin{array}{l}\text { Make contact with teachers to evaluate student } \\
\text { progress }\end{array}$} & Female & 4.0 & \multirow[t]{2}{*}{0.43} \\
\hline & Male & 3.9 & \\
\hline \multirow{2}{*}{$\begin{array}{l}\text { Work with teachers to discover new approaches } \\
\text { for dealing with learning problems }\end{array}$} & Female & 4.0 & \multirow[t]{2}{*}{1.79} \\
\hline & Male & 3.8 & \\
\hline \multirow[t]{2}{*}{ Model creative thinking for staff and student } & Female & 3.8 & \multirow[t]{2}{*}{1.38} \\
\hline & Male & 3.6 & \\
\hline \multirow[t]{2}{*}{ Set specific expectation for student performance } & Female & 4.1 & \multirow[t]{2}{*}{-0.05} \\
\hline & Male & 4.1 & \\
\hline
\end{tabular}

Table 4: Monitoring Students' Progress Scale among Head Teachers of Different Gender

\subsection{Monitor Student Progress}

There was no significant difference in head-teachers' performance in monitoring students' progress among the two genders. 
This is despite the marginal difference that can be noted in the females score for different variables used for evaluating monitoring of students as shown in Table 3.

\begin{tabular}{|c|c|c|c|}
\hline Promotes Instructional climate & $\begin{array}{l}\text { Gender of Head } \\
\text { Teacher }\end{array}$ & Mean & $\mathbf{t}$ \\
\hline \multirow[t]{2}{*}{ Write a letter of recommendation for a job well done } & Female & 3.4 & \multirow[t]{2}{*}{-0.22} \\
\hline & Male & 3.4 & \\
\hline \multirow[t]{2}{*}{ Asks parents to praise teachers for good work } & Female & 3.4 & \multirow[t]{2}{*}{-1.41} \\
\hline & Male & 3.6 & \\
\hline \multirow[t]{2}{*}{ Encourage a teacher to try out a new idea } & Female & 4.0 & \multirow[t]{2}{*}{0.47} \\
\hline & Male & 4.0 & \\
\hline \multirow[t]{2}{*}{ Encourage a teacher to compete for an award } & Female & 3.6 & \multirow[t]{2}{*}{-0.50} \\
\hline & Male & 3.7 & \\
\hline \multirow[t]{2}{*}{ Nominate teachers for awards } & Female & 3.3 & \multirow[t]{2}{*}{-0.84} \\
\hline & Male & 3.4 & \\
\hline \multirow{2}{*}{$\begin{array}{l}\text { Encourage and support a staff member seeking additional } \\
\text { training }\end{array}$} & Female & 4.0 & \multirow[t]{2}{*}{1.10} \\
\hline & Male & 3.8 & \\
\hline \multirow[t]{2}{*}{ Praise staff members for their good work } & Female & 4.2 & \multirow[t]{2}{*}{-0.63} \\
\hline & Male & 4.3 & \\
\hline \multirow[t]{2}{*}{ Join an informal discussion among staff members } & Female & 3.6 & \multirow[t]{2}{*}{$-2.78^{* *}$} \\
\hline & Male & 4.0 & \\
\hline \multirow[t]{2}{*}{ Seeks advice from members in making a decision } & Female & 3.8 & \multirow[t]{2}{*}{-1.97} \\
\hline & Male & 4.0 & \\
\hline \multirow[t]{2}{*}{ Write a memo to staff praising their efforts } & Female & 3.1 & \multirow[t]{2}{*}{-1.89} \\
\hline & Male & 3.4 & \\
\hline \multirow[t]{2}{*}{ Foster regard for teachers among parents } & Female & 3.6 & \multirow[t]{2}{*}{$-2.31^{*}$} \\
\hline & Male & 3.9 & \\
\hline
\end{tabular}

Table 5: Promoting Instructional Climate Scale among Schools with Head Teachers of Different Gender ** - Significant at 0.01, * - Significant At 0.05

\subsection{Promotes Instructional Climate}

There was a significantly higher scoring for joining an informal discussion among staff members in schools with a male head-teacher than those with a female head-teacher.

Fostering regard for teachers among parents scored significantly higher among schools with male head teachers than those with female head teachers.

The rest of variables on promoting instructional climate did not score significantly between schools managed by female and male head teachers as revealed in Table 5.

\section{Discussions and Conclusion}

The specific objective for this study was to establish if differences existed between instructional leadership style and the demographic characteristic of gender among head-teachers of primary schools of KiambuCounty, Kenya.

The findings were discussed according to the dimensions of define mission, supervision of teaching, management of curriculum, monitoring of student progress and promoting instructional climate. The summary of the study findings are presented in Table 6 and 7.

The results showed that on the overall, the statistical findings of the study indicated that head-teachers of both genders had a positive perception of the instructional leadership style and that to some extent both genders had adopted the instructional leadership style in their respective schools at a Mean of between 4.22 to 3.65. However, the dimensions of defines mission (Mean: 4.22), Management of curriculum (Mean: 4.12) and supervision of teaching (Mean: 4.05) were perceived positively higher as demonstrated in Table 6.

\begin{tabular}{|c|c|c|c|}
\hline \multirow{2}{*}{ Instructional Leadership Styles } & \multicolumn{3}{|c|}{ Gender of Head Teachers (Mean \pm SD) } \\
\cline { 2 - 4 } & Male & Female & Total \\
\hline Managed curriculum & $4.12 \pm 0.726$ & $4.03 \pm 0.930$ & $4.09 \pm 0.801$ \\
\hline Supervised teaching & $4.05 \pm 0.847$ & $3.97 \pm 1.007$ & $4.03 \pm 0.904$ \\
\hline Monitored students' progress & $3.92 \pm 0.841$ & $3.90 \pm 0.979$ & $3.91 \pm 0.889$ \\
\hline Defined mission & $4.25 \pm 0.808$ & $4.16 \pm 0.956$ & $4.22 \pm 0.860$ \\
\hline Promoted instructional culture & $3.72 \pm 0.965$ & $3.51 \pm 0.985$ & $3.65 \pm 0.974$ \\
\hline
\end{tabular}

Table 6: Descriptive Statistics for Instructional Leadership Styles by Gender 
However, 4 out of 46 variables in the five dimensions had significant results at $p<0.01$ and 0.05 respectively among head-teachers of different genders as explained below:

Looking at the management of the curriculum scale we find one variable that was scored significantly different from the others: thus finding resources to help staff do a good job was significantly scored higher for females than males. According to Chliwniak, (1997), females and males as educational leaders, carry out the same tasks but often focusing on the different aspects of the same job.

In supervision of teaching, among head-teachers of different genders, one variable of spending time working on teaching skills with a teacher stood out and was scored significantly higher by females at a mean score of 3.9 while males had 3.6 with a t of 2.64. Principal's supervisory activities are paramount in improving teaching and learning and that while male and female principals could perform the same tasks, their emphasis of the importance of these tasks make a difference. Consequently, in performing their tasks as principals, women tend to spend more time observing in classrooms and discussing instructional strategies and curricula with teachers (Varley, 2005). Promoting instructional climate revealed significant differences in two areas where males scored significantly higher than females in the variables of joining an informal discussion among staff members in schools and Fostering regard for teachers among parents. Literature review demonstrated that the attention given by the principals in promoting instructional climate could be different depending on gender, the location of school (urban or rural) or vary among individual (age, gender etc.).To be specific, male and female head-teachers may have different ideologies in promoting instructional climate in their schools (Egwu, 2015).

From the preceding, the overall results show no significant differences between females and males when using instructional leadership style, as demonstrated in the ANOVA results which were used to investigate whether the mean ratings were significantly different. As illustrated in Table 7-11, the study findings revealed no significant difference between gender of the head-teacher and the use of instructional leadership style based on the four dimensions of manages curriculum, supervised teaching, defined mission, Monitored students' progress and promotes instructional climate.

\subsection{Hypothesis 1}

- $\mathrm{H}_{0}$ :There is no significant difference between gender and Managing Curriculum

- $\mathrm{H}_{1}$ :There is significant difference between gender and Managing Curriculum

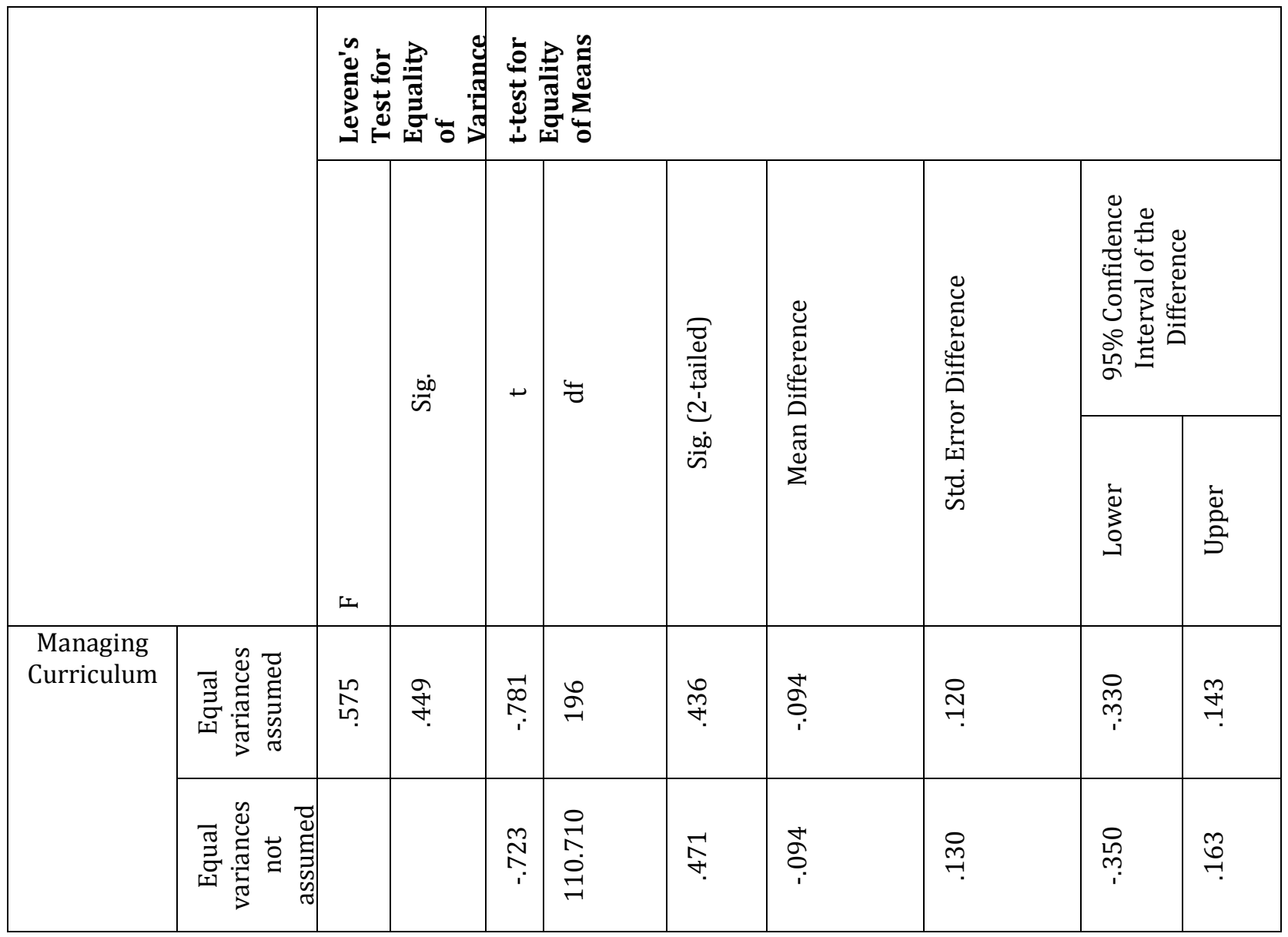

Table 7: Independent Samples T-Test between Gender and Managing Curriculum

The study findings depicted in Table 7 shows that the null hypothesis is accepted which implies that there is no significant difference between gender and managed curriculum $(t=-0.781, P=0.436)$. Hence it can be concluded that there was no significant relationship between gender and managing curriculum. 


\subsection{Hypothesis 2}

- $\mathrm{H}_{0}$ : There is no significant difference between gender and supervised teaching

- $\mathrm{H}_{1}$ : There is significant difference between gender and supervised teaching

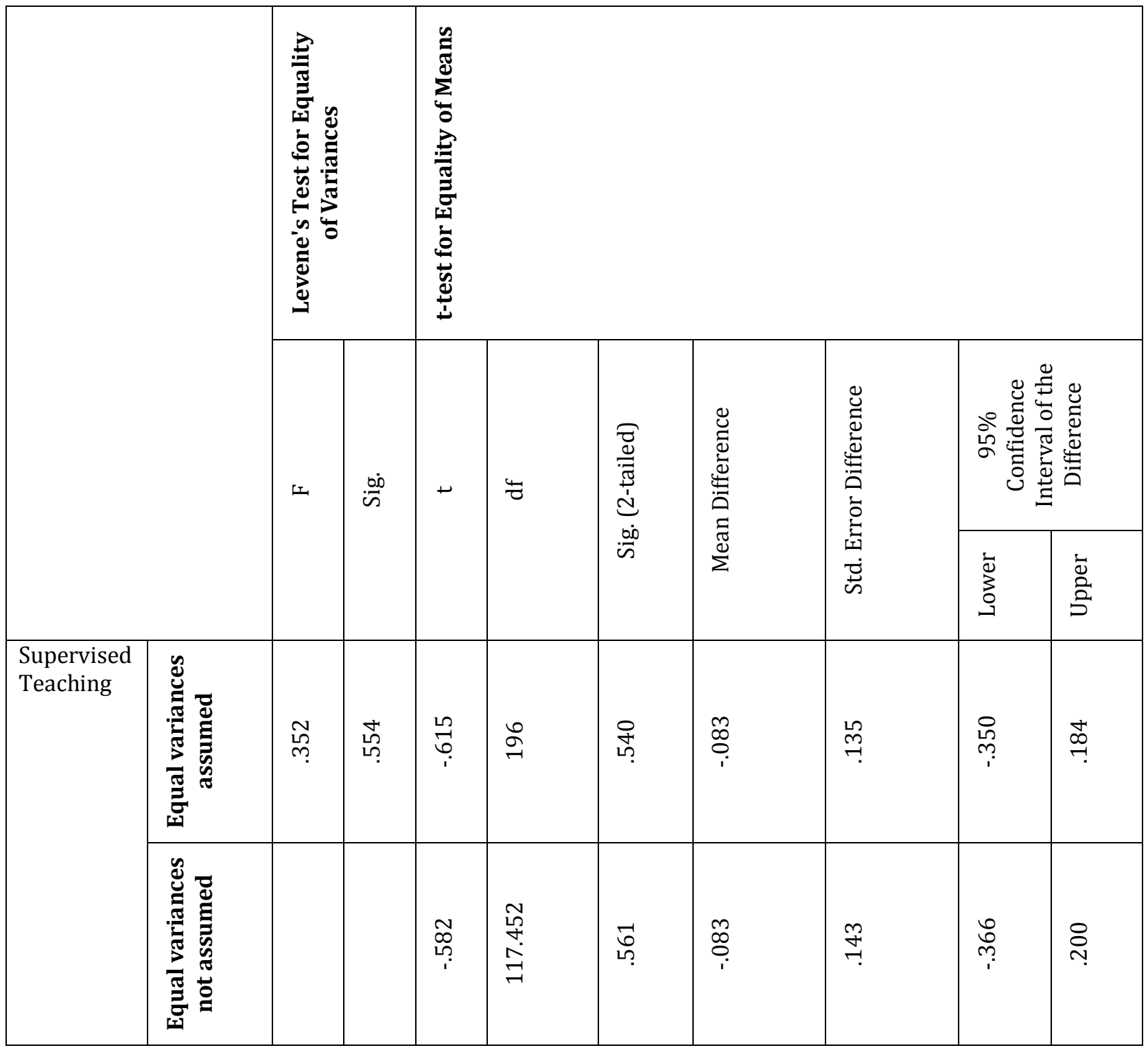

Table 8: Independent Samples T-Test between Gender and Supervises Teaching

The study findings depicted in Table 8 shows that the null hypothesis is accepted which implies that there is no statistical difference between gender and supervision of teaching $(t=-0.615, \mathrm{P}=0.540)$. This meant further that there was no significant relationship between gender and supervised teaching.

\subsection{Hypothesis 3}

- $\mathrm{H}_{0}$ : There is no statistical difference between gender and monitored students progress

- $\mathrm{H}_{1}$ : There is statistical difference between gender and monitored students progress 


\begin{tabular}{|c|c|c|c|c|c|c|c|c|c|c|}
\hline & \multicolumn{2}{|c|}{ 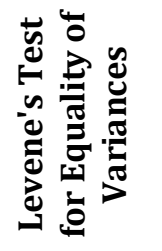 } & \multicolumn{7}{|c|}{ 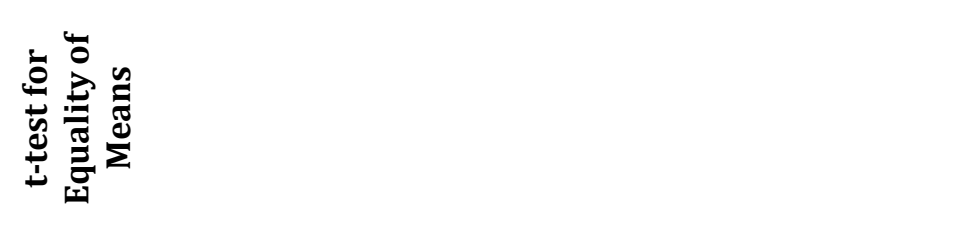 } \\
\hline & & \multirow{2}{*}{ L } & \multirow{2}{*}{$\ddot{\omega n}$} & \multirow{2}{*}{$\omega$} & \multirow{2}{*}{$\pi$} & \multirow{2}{*}{ 苞 } & \multirow{2}{*}{ 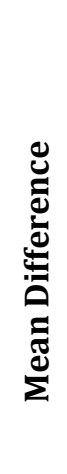 } & \multirow{2}{*}{ 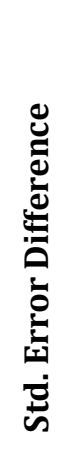 } & \multicolumn{2}{|c|}{ 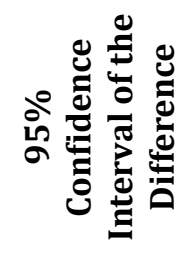 } \\
\hline & & & & & & & & & పे & $\frac{\grave{d}}{\grave{a}}$ \\
\hline \multirow[t]{2}{*}{$\begin{array}{l}\text { Monitor } \\
\text { Student } \\
\text { Progress }\end{array}$} & 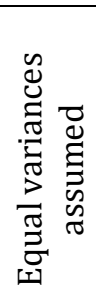 & $\begin{array}{l}\infty \\
\underset{\infty}{\infty}\end{array}$ & $\begin{array}{l}\vec{b} \\
\text { nె }\end{array}$ & $\stackrel{\text { L }}{\stackrel{1}{7}}$ & $\stackrel{\circ}{\circ}$ & 늄 & $\begin{array}{l}\text { Oे } \\
\text { O̦ }\end{array}$ & $\stackrel{m}{\rightarrow}$ & 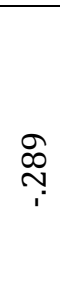 & $\stackrel{\text { }}{\text { ஸ̣ }}$ \\
\hline & 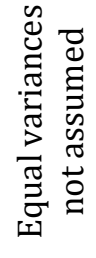 & & & $\begin{array}{l}\infty \\
\stackrel{\infty}{7}\end{array}$ & 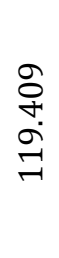 & $\begin{array}{l}n \\
\stackrel{2}{L} \\
\infty\end{array}$ & 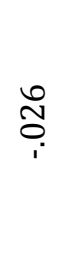 & $\stackrel{\circ}{+}$ & ஜి & 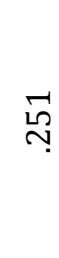 \\
\hline
\end{tabular}

Table 9: Independent Samples t-test between Gender and Monitor Student Progress

The study findings depicted in Table 9 shows that the null hypothesis is accepted which implies that there is no statistical difference between gender and monitored students' progress $(t=-0.195, P=0.845)$. Hence, it can be concluded that there was no significant relationship between gender and monitor students' progress.

\subsection{Hypothesis 4}

- $\mathrm{H}_{0}$ : There is no significant difference between gender and define mission

- $\mathrm{H}_{1}$ : There is significant difference between gender and define mission 


\begin{tabular}{|c|c|c|c|c|c|c|c|c|c|c|}
\hline & \multicolumn{2}{|c|}{ 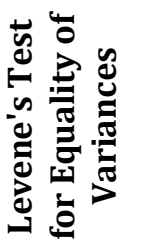 } & \multicolumn{7}{|c|}{ 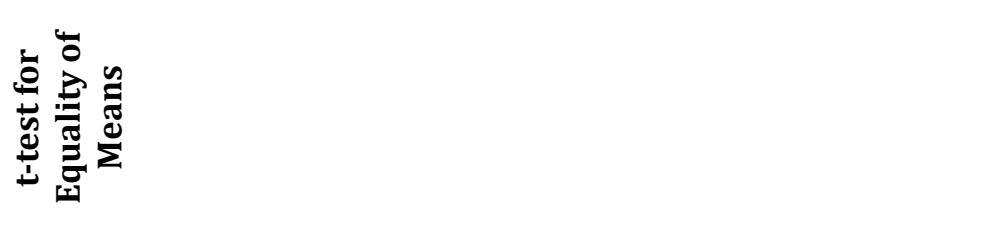 } \\
\hline & & \multirow[t]{2}{*}{ I } & \multirow{2}{*}{$\stackrel{\Delta 00}{\vec{n}}$} & \multirow[t]{2}{*}{-} & \multirow[t]{2}{*}{ 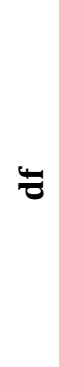 } & \multirow{2}{*}{ 苞 } & \multirow{2}{*}{ 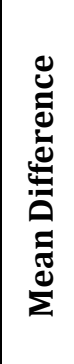 } & \multirow{2}{*}{ 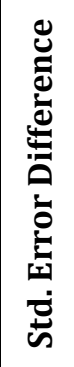 } & \multicolumn{2}{|c|}{ 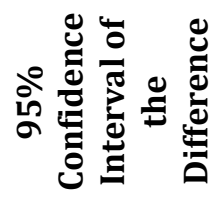 } \\
\hline & & & & & & & & & $\begin{array}{l}\vdots \\
\vdots \\
\vdots \\
0\end{array}$ & 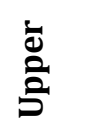 \\
\hline \multirow[t]{2}{*}{$\begin{array}{l}\text { Defines } \\
\text { Mission }\end{array}$} & 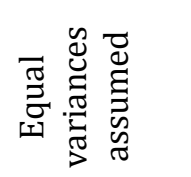 & ஜे & $\begin{array}{l}\mathscr{m} \\
\infty \\
\stackrel{1}{?}\end{array}$ & 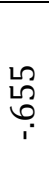 & $\stackrel{\varrho}{\rightarrow}$ & $\stackrel{m}{\text { เก }}$ & 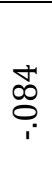 & $\stackrel{\text { }}{\sim}$ & $\underset{\ddot{m}}{\ddot{p}}$ & $\stackrel{?}{\stackrel{1}{7}}$ \\
\hline & 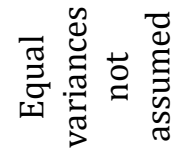 & & & స్ & 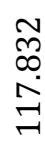 & $\begin{array}{l}\text { } \\
\text { ñ? }\end{array}$ & 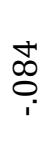 & 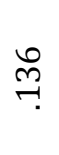 & 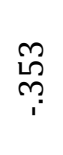 & $\begin{array}{l}\stackrel{L}{\infty} \\
\stackrel{\longrightarrow}{\longrightarrow}\end{array}$ \\
\hline
\end{tabular}

Table 10: Independent Samples T-Test between Gender and Defines Mission

The study findings depicted in Table 10 shows that the null hypothesis is accepted which implies that there is no statistical difference between gender and defined mission $(t=-0.655, P=0.513)$. This is a clear indication that there was no significant relationship between gender and defined mission.

\subsection{Hypothesis 5}

- $\mathrm{H}_{0}$ : There is no significant difference between gender and promote instructional climate

- $\mathrm{H}_{1}$ : There is significant difference between gender and promote instructional climate

\begin{tabular}{|c|c|c|c|c|c|c|c|c|c|c|}
\hline & \multicolumn{2}{|c|}{ 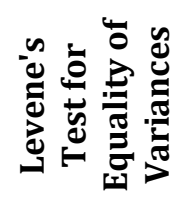 } & \multicolumn{7}{|c|}{ 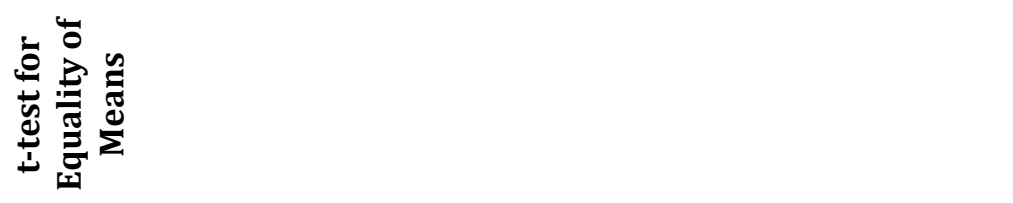 } \\
\hline & & \multirow[t]{2}{*}{ I } & \multirow[t]{2}{*}{$\ddot{000}$} & \multirow[t]{2}{*}{-} & \multirow[t]{2}{*}{$\Psi$} & \multirow{2}{*}{ 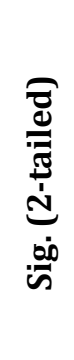 } & \multirow{2}{*}{ 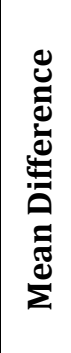 } & \multirow{2}{*}{ 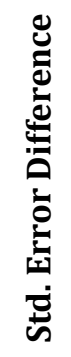 } & \multicolumn{2}{|c|}{ مे } \\
\hline & & & & & & & & & 㐫 & $\begin{array}{l}\dot{\Xi} \\
\text { : }\end{array}$ \\
\hline \multirow[t]{2}{*}{$\begin{array}{l}\text { Promote } \\
\text { Instructional } \\
\text { Culture }\end{array}$} & 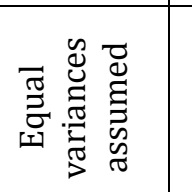 & $\frac{0}{\stackrel{1}{r}}$ & 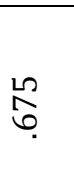 & 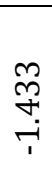 & $\stackrel{\circ}{\stackrel{2}{\sim}}$ & م⿱ & 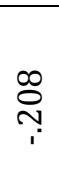 & 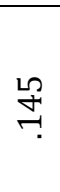 & 尔 & $\begin{array}{l}\infty \\
\stackrel{\infty}{0}\end{array}$ \\
\hline & 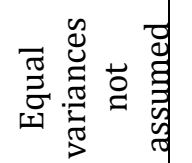 & & & & $\begin{array}{l}\stackrel{L}{0} \\
\stackrel{\sigma}{0} \\
\stackrel{m}{\sim}\end{array}$ & 늠 & $\begin{array}{l}\stackrel{\infty}{\circ} \\
\text { † }\end{array}$ & 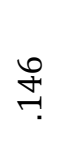 & 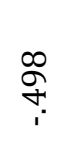 & 离 \\
\hline
\end{tabular}

Table 11: Independent Samples t-test between Gender and Promote Instructional Culture 
The study findings depicted in Table 11 shows that the null hypothesis is accepted which implies that there was no significant difference between gender and promote instructional climate $(\mathrm{t}=-1.433, \mathrm{P}=0.153)$. Hence, it can be concluded that there was no significant relationship between gender and promote instructional climate.

Subsequently since no particular gender had statistical significant results on the dimensions or on majority of the variables or items of instructional leadership behaviours, this could imply that for the head-teachers in Kiambu County, there is no difference between demographic characteristic of gender (male and female) and the use of instructional leadership style. This research is in conflict with meta-analysis study findings carried out by various researchers which demonstrated that female principals engage in more active instructional leadership than their male counterparts (Hallinger et al, (2016), Shaked et al., (2019) and Reis\&Hope, (2019).However, the present study confirms Onele\&AjaOkorie (2015) findings. Perusing through literature one finds majority of studies carried out on the relationship between gender and instructional leadership style have been at secondary school level while studies on the relationship between instructional leadership style and gender of the head-teacher carried out at primary school level are almost nonexistence. That notwithstanding, some authors have contended that leadership style differences are highly situational and conditional to various internal and external environments of the leader (Zaccaro, et al., 2018). This argument is in line with contingency theory which identifies that leadership success depends on the principal's interaction behavior and the location (Riggio, 2008, Chaluvadi, 2015). With that in mind a study carried out in South Africa which could apply to a Kenyan situation revealed that the bulk of the principals never undergo adequate specialist training in financial management and instructional leadership style(Mafuwane, 2012). This could be the reason as to why Mulkeen et al. (2007) asserted that principals in most African countries do not view instructional supervision as part of their duties.

In this particular study, the number of male head-teacher was higher compared to females. Out of 198 distributions of the head-teachers who completed the questionnaire, 130 (66\%) were males while 68 (34\%) were females proving that female head-teacher positions in the Kiambu region are grossly under-represented. In Kenya and in most African countries, women constitute the majority of teachers in primary schools but only occupy the lower ranks in the profession with most of the senior or supervisory and administrative positions occupied by males. For example in Kenya, female teachers are more than $60 \%$ but only $42-45 \%$ of them occupy senior positions (Combat, 2014). The claim on the shortage of women in school leadership position has been supported by Clisbee (2005) in Onele \& Aja-Okorie (2015) who asserts that despite women being a majority at the instructional level, in school leadership positions, there is a global shortage of females. However, Onele \& Aja-Okorie (2015) opined that in the formation and execution of organizational policies and instructional programs, both female and male school heads should show uniformity while at the same time playing very active roles.

In conclusion, findings arising from this study demonstrated that there was no significant statistical difference between the demographic characteristic of gender and use of instructional leadership style. Important implication for this study is that it entails the consideration of educational policy makers in that even though women underrepresentation in school leadership warrants scrutiny, the gender aspect could be downplayed in the selection of head-teachers and instead the education system should concentrate on equipping the schools with the necessary facilities needed in order to expedite the head-teacher become better instructional leaders. Moreover this particular study on gender differences in instructional Leadership Styles among primary head-teachers in Kenya was premeditated as a result of limited literature and growing interest in instructional leadership style and therefore the study contributes to the body of knowledge on how instructional leadership style could be amalgamated into the wider formation of educational leadership. However the validity of this research is limited because the sample was taken from one out of a total of 47Counties and as such, the gender differences in instructional Leadership Styles could be further investigated on a larger scale in primary school in order to understand this particular concept better.

\section{References}

i. Aldahan, R. (2020). The Role of Follower Characteristics in Ratings of Leadership Style: A Meta-Analytic Review.

ii. Alonderiene, R., \& Majauskaite, M. (2016). Leadership style and job satisfaction in higher education institutions. International Journal of Educational Management.

iii. Barbuto Jr., J. E, Fritz, S. M., Matkin, G. S., \& Marx, D. B. (2007). Effects of gender, education, and age upon leaders' use of influence tactics and full range leadership behaviors. Sex Roles, 56(1/2), 71-83. http://dx.doi.org/10.1007/s11199-006-9152-6

iv. Bell, C., Rvanniekerk, R., \& Nel, P. (2015). The relationship between some demographic variables and leadership effectiveness among local government managers in South Africa. African Journal of Business Management, 9(2), 5058.

v. Bellibas, M. S., \& Liu, Y. (2017). Multilevel analysis of the relationship between principals' perceived practices of instructional leadership and teachers' self-efficacy perceptions. Journal of Educational Administration.

vi. Bush, T. (2020). Turnaround leadership in education: A restatement of heroic leadership or a flawed concept: Educational Management and Administration \& Leadership Volume: 48 issue: 1,page(s): 3-5

vii. Bella, N. (2005). VII. Impact of demographic trends on the achievement of the millennium development goal of universal primary education.

viii. Bush, T., \& Glover, D. (2014). School leadership models: What do we know? School Leadership \& Management, 34(5), 553-571.

ix. Chaluvadi, N. S. S. L. (2015). Differences in leadership styles between genders: Outcomes and effectiveness of women in leadership roles. Differences, 2, 19-2015. 
x. Chen, Y. F., Wang, C. M., \& Lin, H. J. (2006). Explore the relationships among demography, personality traits and self-directed learning. The Journal, 141.

xi. Chliwniak, L. (1997). Higher Education Leadership: Analyzing the Gender Gap. ASHE-ERIC Higher Education Report, Vol. 25, No. 4. ERIC Clearinghouse on Higher Education, The George Washington University, One Dupont Circle, Suite 630, Washington, DC 20036-1183.

xii. Combat, V. F. (2014). Women Aspiring to Administrative Positions in Kenya Municipal Primary Schools. International journal of Educational Administration and Policy studies, 6(7), 119-130.

xiii. Conoley, J. C., Impara, J. C., \& Murphy, L. L. (1995). The twelfth mental measurements year book. Lincoln, NE: Buros Institute of Mental Measurements, 489-496.

xiv. Conoley, J. C., Impara, J. C., \& Murphy, L. L. (1995). The twelfth mental measurements year book. Lincoln, NE: Buros Institute of Mental Measurements, 489-496.

xv. DuBrin, A. J. (2009). The Complete Guides Leadership. Edisi Kedua. Prenada Media Grup. cetakan ke-3.

xvi. Due Billing, Y., \& Alvesson, M. (2000). Questioning the notion of feminine leadership: A critical perspective on the gender labelling of leadership. Gender, Work \& Organization, 7(3), 144-157.

xvii. Eagly, A. H., \& Johnson, B. T. (1990). Gender and leadership style: A meta-analysis. Psychological Bulletin, 108, 23256.

xviii. Eagly, A. H., Makhijani, M. G., \& Klonsky, B. G. (1992). Gender and the evaluation of leaders: A metaanalysis. Psychological bulletin, 111(1), 3.

xix. Eagly, A. H., \& Carli, L. L. (2003). The female leadership advantage: An evaluation of the evidence. The leadership quarterly, 14(6), 807-834.

xx. Egwu, S. O. (2015). Attitude of Students towards Teaching Profession in Nigeria: Implications for Education Development. Journal of Education and Practice, 6(29), 21-25.

xxi. Elfil, M., \& Negida, A. (2017). Sampling methods in clinical research; an educational review. Emergency, 5(1).

xxii. Hallinger, P. (2005). Instructional leadership and the school principal: A passing fancy that refuses to fade away. Leadership and Policy in Schools, 4(3), 8-9.

xxiii. Hallinger P., Dongyu Li, Chung W. W. (2009). Gender Differences in Instructional Leadership: A Meta-Analytic Review of Studies Using the Principal Instructional Management Rating ScaleEducational Administration Quarterly; Doi: 10.1177/0013161x16638430 SAGE Publication.

xxiv. Hallinger, P. (2012), "A data-driven approach to assess and develop instructional leadership with the PIMRS", in Shen, J. (Ed.), Tools for Improving Head-teachers' Work, Peter Lang Publishing, New York, NY, pp. 47-69.

xxv. Hallinger, P., Dongyu, L., \& Wang, W. C. (2016). Gender differences in instructional leadership: A meta-analytic review of studies using the principal instructional management rating scale. Educational Administration Quarterly, 52(4), 567-601.

xxvi. Ibukun, W. O., Oyewole, B. K., \& Abe, T. O. (2011). Personality characteristics and principal leadership effectiveness in Ekiti State, Nigeria. International Journal of Leadership Studies, 6(2), 247-262.

xxvii. Kabacoff, R. I. (2002). Leadership: What has age got to do with it? Research release. New York: Management Research Group.

xxviii. Kabacoff, R. I., \& Stoffey, R. W. (2001). Age differences in organisational leadership. Paper presented at 16th Annual Conference of the Society for Industrial and Organisational Psychology. San Diego, CA, USA.

xxix. Karau, S. J., \& Eagly, A. H. (1999). Invited reaction: Gender, social roles, and the emergence of leaders. Human Resource Development Quarterly, 10(4), 321.

xxx. Kim, H. S., \& Shim, S. (2003). Gender-based approach to the understanding of leadership roles among retail managers. Human Resource Development Quarterly, 14(3), 321-342.

xxxi. Krishnan, H. A., \& Park, D. (1998). Effects of top management team change on performance in downsized US companies. MIR: Management International Review, 303-319.

xxxii. Kwan, P. (2020). Is Transformational Leadership Theory Passé? Revisiting the Integrative Effect of Instructional Leadership and Transformational Leadership on Student Outcomes. Educational Administration Quarterly, 56(2), 321-349.

xxxiii. Kyriakidou, O., Kyriacou, O., Özbilgin, M., \& Dedoulis, E. (2016). Equality, diversity and inclusion in accounting. Critical perspectives on accounting, 35, 1-12.

xxxiv. Leithwood, K. Day, C. Sammons, P. Harris, A, \& Hopkins, D. (2006). Successful School Leadership: What It Is and How It Influences Pupil Learning. National college for school leadership Research Report RR800.

xxxv. Llewellyn, D. J., \& Wilson, K. M. (2003). The controversial role of personality traits in entrepreneurial psychology. Education+ Training.

xxxvi. Lojpur, A., Aleksić A., Vlahović S., Pejić M., Peković S. (2014). Examining Determinants of Leadership Style among Montenegrin Managers. Vol. 61 No. 1 / February 2015. DOI:

xxxvii. Mafuwane, B. M. (2012). The contribution of instructional leadership to learner performance (Doctoral dissertation, University of Pretoria).

xxxviii. Manning, T. T. (2002). Gender, managerial level, transformational leadership and work satisfaction. Women in management review.

xxxix. Marks, H.M. \& Printy, S. M. (2003). Principal leadership and school performance: Integrating transformational and instructional leadership. Educational Administration Quarterly, 39(3), pp. 370-397.

xl. Moran, B. B. (1992). Gender differences in leadership. Library trends, 40(3), 475-491. 
xli. Muchiri, M. K., Cooksey, R. W., Di Milia, L. V., \& Walumbwa, F. O. (2011). Gender and managerial level differences in perceptions of effective leadership. Leadership \& Organization Development Journal.

xlii. Mulkeen, A., Chapman, D.W., DeJaghere, J.G. \& Leu, E. (2007). Recruiting, retaining, and retraining secondary school teachers and principals in Sub-Saharan Africa. Washington, D.C: World Bank.

xliii. Mutea, Z. K. (2015). Relationship between instructional practices and standard four pupils' achievement in English in public primary schools in Nairobi city county, Kenya. (Doctoral dissertation, University of Nairobi).

xliv. Mutuku, M. P., Njuguna, W. F., \& Ogola, M (2017). Relationship between head-teachers'instructional leadership practices and the academic performance of students in machakos county, Kenya. European Journal of Education Studies.

xlv. Novel, N. J. A., \& Purbasari, R. (2017). Leadership styles of women entrepreneurs in the field of culinary and fashion of Ikatan Wanita Pengusaha Indonesia (IWAPI) Bandung. Review of Integrative Business and Economics Research, 6, 143.

xlvi. Ombonga, M., \& Ongaga, K. 1. 2017. Instructional Leadership: A Contextual Analysis of Head-teachers in Kenya and Southeast North Carolina Journal of Education and Practice Vol.8, No.17, 2017

xlvii. Onele-Adali, A., \& Aja-Okorie, U. (2015) Gender differences in administration of secondary schools in Ebonyi State, Nigeria. International Journal of Multidisciplinary Research and Development, 2(10), 61-66.

xlviii. Ponton, M., Derrick, M. G., \& Carr, P. B. (2005). The relationship between resourcefulness and persistence in adult autonomous learning. Adult Education Quarterly, 55(2), 116-128. Roberson D. N. J. \& Merriam S. B. (2005).The Self-Directed Learning Process of Older, Rural Adults. Adult Education Quarterly, (55) 4. 269-287.

xlix. Rahman, H. A., \& Lim, S. H. (2018). Gender Differences in Leadership Styles among Rural School Headmasters in Malaysia.

l. Riggio, R. E. (2008). Leadership development: The current state and future expectations. Consulting Psychology Journal: Practice and Research, 60, 383-392.

li. Robinson, V., Hohepa, M. \& Lloyd, C. (2009). School leadership and student outcomes: identifying what works and why. Best Evidence Syntheses Iteration (BES). New Zealand: Ministry of Education. [Online] Available from: http://www.educationcounts. govt.nz/publications/series/2515/60169/60170 [Accessed July 2013]

lii. sakeni, M., Munje, P. N., \& Jita, L. C. (2020). Instructional leadership sensemaking for science and maths in South African multi-deprived middle schools. Issues in Educational Research, 30(1), 345-364.

liii. Shadare, O. A. (2011). Management styles and demographic factors as predictors of managerial efficiency in work organizations in Nigeria. International Business and Economic Research Journal, 10(7):85-94.

liv. Shaked, H., Gross, Z., \& Glanz, J. (2019). Between Venus and Mars: Sources of gender differences in instructional leadership. Educational Management Administration \& Leadership, 47(2), 291-309.

lv. Sheikh, A. G. (2001). Leadership styles as viewed by secondary school head teachers of Lahore City. Hamdard University Karachi Pakistan: Master thesis.

lvi. Tabassi, A. A., \& Bakar, A. H. A. (2010). Towards assessing the leadership style and quality of transformational leadership. Journal of Technology Management in China.

lvii. Ünal-Karagüven, M. H. (2015). Demographic Factors and Communal Mastery as Predictors of Academic Motivation and Test Anxiety. Journal of Education and Training Studies, 3(3), 1-12.

lviii. Varley, S. M. (2005). Supervisory practices of three female principals in the era of No Child Left Behind (Doctoral dissertation, University of Pittsburgh).

lix. Wambui, M., Tanui, E., \& Ngaruiya, B. (2016). Relationship between Principal's instructional leadership role and students' subject choice in Public secondary schools in Nairobi County, Kenya

lx. Zaccaro, S. J., Green, J. P., Dubrow, S., \& Kolze, M. (2018). Leader individual differences, situational parameters, and leadership outcomes: A comprehensive review and integration. The Leadership Quarterly, 29(1), 2-43. 